\title{
Effect of Cytochalasin B and D on Groups of Insulin Receptors and on Insulin Action in Rat Adipocytes
}

\author{
POSSIBLE EVIDENCE FOR A STRUCTURAL RELATIONSHIP OF THE \\ INSULIN RECEPTOR TO THE GLUCOSE TRANSPORT SYSTEM
}

\author{
LeOnard Jarett and Robert M. Smith, Division of Laboratory Medicine, \\ Departments of Pathology and Medicine, Washington University \\ School of Medicine, and Barnes Hospital, St. Louis, Missouri 63110
}

A B S T R A C T The possible physiological importance of the groups of insulin receptors on rat adipocytes and the relationship of these groups to insulin action were investigated. The effect of cytochalasin B and D on biological actions of insulin was measured and compared with the effect of these agents on the ultrastructural distribution of groups of insulin receptors. Cytochalasin B had no effect on epinephrine-stimulated lipolysis, insulin inhibition of epinephrine-stimulated lipolysis, or insulin stimulation of protein synthesis. Cytochalasin B, over a concentration range of $50 \mathrm{nM}$ to $5 \mu \mathrm{M}$, progressively inhibited the basal glucose transport system, as measured by glucose oxidation, 2-deoxyglucose transport, and 3-O-methylglucose transport. Insulin was capable of fully stimulating remaining basal transport at submaximal concentrations of cytochalasin B. Insulin pretreatment of adipocytes partially protected the glucose transport system from inhibition by cytochalasin B. Cytochalasin B markedly altered the distribution pattern of insulin receptors, which caused an increase in the number of single receptor molecules by decreasing the number of larger groups. A significant correlation $(r=0.964 ; P<0.001)$ was found between the percent increase in single receptors and the percent decrease in glucose transport. Ferritin-insulin pretreatment of adipocytes prevented disruption of the groups of insulin receptors by cytochalasin B. Cytochalasin D had no effect on the biological actions of insulin or on the groups of insulin receptors. These data suggest that the ability of insulin

This study was presented in part at the Annual Meeting of the American Society for Cell Biology in San Diego, Calif., November 1977, and at the Endocrine Society in Chicago, Ill., June 1977.

Received for publication 15 August 1978 and in revised form 4 December 1978. to affect adipocyte metabolism is independent of the hormone occupying adjacent, grouped receptor sites. The marked contrast in effects of cytochalasin B and $\mathrm{D}$ on groups of insulin receptors and glucose transport suggests that the microfilament system is not involved in insulin action or in holding the groups of insulin receptors together, as both agents are known disrupters of microfilaments and inhibitors of actin gelation. The correlation between the effects of cytochalasin $B$ on insulin receptor distribution and glucose transport leads to the speculation that the glycoprotein molecules containing the insulin receptor are functionally linked with the glucose transport system.

\section{INTRODUCTION}

It is generally accepted that insulin initially interacts with specific receptors on the plasma membrane of cells. This has been demonstrated by both biochemical $(1,2)$ and morphological techniques (3). With ferritininsulin we have shown that the insulin receptors on rat adipocytes are distributed on the surface of the cell associated with the glycocalyx region of the plasma membrane (4-6). The receptors were visualized either as single receptors or in groups of two to six. The groups were shown to occur before, and independent of, the binding of the hormone to the receptor.

This study attempted to determine the possible physiological importance of these groups of insulin receptors and to determine if they were essential to insulin action. The experimental design was to attempt to disrupt the groups of receptors by a chemical agent and relate this to alterations in the biological responses to insulin. Cytochalasin B was chosen as the pharmacological tool for disrupting the groups of insulin receptors for several reasons. Cytochalasin B is known 
to disrupt clusters of aggregated receptors (7) and intramembranous particles (8), possibly through its actions on microfilaments and actin (9). This agent has been used to inhibit basal and insulin-stimulated glucose transport (10), but has been shown not to affect numerous other insulin-sensitive processes (11), including both membrane-localized and intracellular responses. The unaffected membrane processes include $\alpha$ aminoisobutyrate transport and a specific fructose transport system, whereas the unaffected intracellular insulin-sensitive action was the antilipolytic effect of the hormone. Data from this report demonstrate that disruption of groups of insulin receptors by cytochalasin B does not prevent insulin from exerting its action. However, disruption of the groups of insulin receptors correlated with the inhibition of the basal glucose transport system, which suggests that some of the insulin receptors are on the same glycoproteins which form the glucose transport system.

\section{METHODS}

Preparation of isolated adipocytes. Adipocytes were prepared as described by Rodbell (12). Minced epididymal fat pads from 120-g male Wistar rats were incubated in KrebsRinger phosphate buffer containing one-half the normal calcium concentration, $3 \%$ bovine serum albumin (BSA), ${ }^{1}$ and $0.2 \%$ dextrose with $1 \mathrm{mg}$ crude collagenase per milliliter at $\mathrm{pH}$ 7.4. The pads were digested for $40-45 \mathrm{~min}$ at $37^{\circ} \mathrm{C}$, after which the contents of the digestion flasks were filtered through a silk screen. The cells in the filtrate were centrifuged at $800 \mathrm{~g}$ for $30 \mathrm{~s}$, and the infranatant was aspirated. The cells were washed three times by resuspension and centrifugation in Krebs-Ringer phosphate buffer with BSA and dextrose as above. Dextrose was omitted from the washing buffer of cells to be used for glucose oxidation or transport studies. After the final wash, the cells were resuspended in the wash buffer to a concentration of $\cong 10^{6}$ cell $\mathrm{s} / \mathrm{ml}$ and allowed to equilibrate at $37^{\circ} \mathrm{C}$ for $15 \mathrm{~min}$ before beginning any assay. Protein measurements of whole-cell suspensions were determined by performing cell counts as previously described (13).

Biochemical studies. Adipocyte lipolysis was determined by measuring the amount of glycerol released during a 30min incubation at $37^{\circ} \mathrm{C}(13)$. Triplicate vials were prepared which contained $(a)$ epinephrine $(0.125 \mu \mathrm{g} / \mathrm{ml} ;(b)$ cytochalasin B $(1 \mu \mathrm{M}) ;(c)$ insulin $(50 \mu \mathrm{U} / \mathrm{ml})$ in the presence of epinephrine; or $(d)$ insulin, epinephrine, and cytochalasin B. A set of control vials had no additions. Equilibrated adipocytes were added to bring the incubation volume to $\mathrm{l} \mathrm{ml}$. The incubations were ended after $30 \mathrm{~min}$ by the addition of $0.3 \mathrm{ml}$ $2 \mathrm{~N}$ perchloric acid. The extract was transferred to centrifuge tubes, and the extracted protein was sedimented. The infranatant was removed and neutralized before assay for glycerol as described by Lowry et al. (14).

The incorporation of $\left[{ }^{14} \mathrm{C}\right]$ histidine into protein was measured as previously described (13). Equilibrated adipocytes were added to vials which contained $0.5 \mu \mathrm{Ci}\left[{ }^{14} \mathrm{C}\right]$ histidine and the various agents being tested, to bring the final volume to $1 \mathrm{ml}$. After $30 \mathrm{~min}$ of incubation at $37^{\circ} \mathrm{C}$, aliquots were

${ }^{1}$ Abbreviations used in this paper: BSA, bovine serum albumin; Fm-I, monomeric ferritin-insulin; PBS-BSA, phosphate-buffered saline containing $0.1 \%$ BSA. removed from the vials to $2.54-\mathrm{cm}$ squares of Whatman filter paper (Whatman, Inc., Clifton, N. J.). The protein was precipitated by immersing the filter papers in cold, $10 \%$ TCA following the procedure of Mans and Novelli (15) as modified for adipocytes (13). The filters were air dried, then placed in liquid scintillation vials containing $15 \mathrm{ml}$ toluene-Omnifluor (New England Nuclear, Boston, Mass.) and counted in a liquid scintillation counter.

The effect of cytochalasin $B$ on insulin binding was determined by incubating $10^{5}$ cells $/ \mathrm{ml}$ for $15 \mathrm{~min}$ at $37^{\circ} \mathrm{C}$ with $0-20 \mu \mathrm{M}$ cytochalasin B. ${ }^{125} \mathrm{I}-$ labeled insulin $(50 \mu \mathrm{U} / \mathrm{ml}, 0.6$ $\mu \mathrm{Ci})$ was then added to the cells, and the incubation continued for $15 \mathrm{~min}$ at $37^{\circ} \mathrm{C}$. The cell suspensions were diluted with $5 \mathrm{ml}$ cold $0.1 \mathrm{M}$ phosphate-buffered saline containing $0.1 \%$ BSA (PBS-BSA) and decanted onto Whatman GF/C glass fiber filters (Whatman, Inc.). The filters were washed under moderate vacuum with $10 \mathrm{ml}$ of the PBS-BSA buffer. Nonspecific binding of the labeled ligand was determined in the presence of $5 \mu \mathrm{g} / \mathrm{ml}$ of porcine insulin, and the values reported are the corrected or specific binding.

The effect of cytochalasin B or D on basal and insulinstimulated glucose oxidation was determined by adding $5 \times 10^{4}$ cells to vials that contained various concentrations of the cytochalasin from 0 to $20 \mu \mathrm{M}$ in a final volume of $2 \mathrm{ml}$. After $15 \mathrm{~min}$ at $37^{\circ} \mathrm{C}, 50$ or $500 \mu \mathrm{U}$ insulin/ml was added to the appropriate vials and $\mathrm{D}-\left[1-{ }^{14} \mathrm{C}\right]$ glucose $(0.55 \mathrm{mM})$ was added to all vials. The vials were immediately capped. At the end of $60 \mathrm{~min}$ at $37^{\circ} \mathrm{C},{ }^{14} \mathrm{CO}_{2}$ was determined as described by Gliemann (16). For protective effect studies, cells were incubated for $15 \mathrm{~min}$ at $37^{\circ} \mathrm{C}$ with $250 \mu \mathrm{U}$ insulin $/ \mathrm{ml}$ before cytochalasin $\mathrm{B}$ and $\mathrm{D}-\left[1-{ }^{14} \mathrm{C}\right]$ glucose addition.

Transport of $\left[2-{ }^{14} \mathrm{C}\right]$ deoxyglucose and $\left[3-\mathrm{O}-{ }^{3} \mathrm{H}\right]$ methylglucose was determined under similar conditions except that the final incubation volume was $0.25 \mathrm{ml}$, the sugar concentration was $0.1 \mathrm{mM}$, and the incubation time after addition of the radioactive sugar was either $10 \mathrm{~min}$ for 2-deoxyglucose or $10 \mathrm{~s}$ for 3-O-methylglucose. The incubation was terminated by diluting the cell suspension with $3 \mathrm{ml}$ PBS-BSA and decanting the cells onto a Whatman GF/C filter. The filter was washed once with $10 \mathrm{ml}$ PBS-BSA, air dried, and counted for ${ }^{14} \mathrm{C}$ or ${ }^{3} \mathrm{H}$ in a liquid scintillation counter.

Morphological studies. Monomeric ferritin-insulin (Fm-I) was prepared and characterized as previously described (6). The monomeric peak of ferritin was purified on a Bio-Gel A $1.5 \mathrm{M}$ chromatographic column (Bio-Rad Laboratories, Richmond, Calif.). The monomeric ferritin was conjugated to insulin with dilute glutaraldehyde that specifically reacts with lysine residues and does not cross-link ferritin (4-6), which makes the B-29 lysine of insulin the point of crosslinking. The resulting conjugate was repurified on Bio-Gel A $1.5 \mathrm{M}$, revealing only $\mathrm{Fm}-\mathrm{I}$, which confirmed the lack of cross-linking of ferritin by glutaraldehyde. The Fm-I peak was concentrated by centrifugation at $150,000 \mathrm{~g}$ for $2 \mathrm{~h}$, and the pellet was resuspended in $0.1 \mathrm{M} \mathrm{NaPO}_{4}$ buffer $(\mathrm{pH} 7.4$ ) and stored at $4^{\circ} \mathrm{C}$. The biological and immunological activity of the conjugate were assessed by comparison with the original porcine insulin. These activities were equal to each other and revealed that only about $2 \%$ of the ferritin contained insulin as previously reported (4-6), which indicated that only one insulin would be present on one ferritin. Thus, any ferritin core bound to the cells would represent an insulin receptor. The actual Fm-I used in this study was the same as that previously used (6).

Adipocytes were incubated with Fm-I under conditions essentially identical to the biochemical studies. About $10^{6}$ cells were incubated with various concentrations of cytochalasin B or $\mathrm{D}$ for $15 \mathrm{~min}$ at $37^{\circ} \mathrm{C}$ before the addition of $500 \mu \mathrm{U} \mathrm{Fm}-\mathrm{I} /$ $\mathrm{ml}$. For protective effect studies, the cells were incubated 
for $15 \mathrm{~min}$ at $37^{\circ} \mathrm{C}$ with $500 \mu \mathrm{U} \quad \mathrm{Fm}-\mathrm{I} / \mathrm{ml}$ before adding cytochalasin $\mathrm{B}$ or $\mathrm{D}$. The cells were then incubated for $30 \mathrm{~min}$ at $37^{\circ} \mathrm{C}$. The suspension was diluted with cold PBS-BSA and centrifuged at $800 \mathrm{~g}$, and the infranatant was aspirated. The cells were prepared for electron microscopy as previously described in detail (5). Only areas of cells showing ferritin cores were photographed. As previously reported, the adipocyte has $\cong 100$ ferritin-insulin receptors per square micron of plasma membrane (3). It was not feasible, therefore, to photograph entirely at random the entire cell surface in any given section. The validity of the qualitative and quantitative results presented below was assured by careful and strict adherence to several principles and methodological approaches. First, the sectioned specimens were numerically coded in such a manner that the microscopist was unaware of the experimental condition being observed. The entire cell surface of all cells in a given section was carefully observed, and all ferritin cores were photographed. A minimum of 100 micrographs $(\times 33,000)$ were taken of each experimental condition at a uniform magnification. The negatives were printed to yield a final magnification of 90,000 . The distribution of the ferritin-insulin receptors into groups of various sizes were characterized by the proximity of the ferritin cores to each other (Fig. 7 [6]). This was determined independently by at least two persons who were also unaware of the experimental condition being analyzed. The data was tabulated, and the results presented represent the mean of all determinations for a given experimental condition in up to five experiments.

Controls for electron microscopy were performed as previously described (4-6) and included (a) Fm-I plus $5 \mu \mathrm{g} / \mathrm{ml}$ of porcine insulin and $(b)$ the same amount of ferritin as present in the Fm-I. In neither case was more than a few cellassociated ferritin cores seen in multiple sections from multiple blocks as previously reported (4-6), which indicated the almost complete absence of nonspecific binding. There are several reasons for this extremely low nonspecific level compared with the nonspecific binding reported in Fig. 1. The biochemical nonspecific binding included trapped fluid. The extensive washing processes of the fixed cells for morphological studies removes all trapped Fm-I or ferritin. Also, only cell-associated ferritin cores were considered for specific or nonspecific binding.

Materials. Cytochalasin B and D were purchased from Aldrich Chemical Co., Inc., Milwaukee, Wis., and stock solutions were prepared in absolute ethanol. The concentration of ethanol in the incubations $(<0.1 \%)$ was found to be without effect on the biochemical or morphological parameters studied. Wistar rats were from National Animal Laboratories, St. Louis, Mo. Collagenase and BSA were products obtained from Sigma Chemical Co., St. Louis, Mo. Other reagents and products were obtained from standard sources or as detailed in previous reports.

\section{RESULTS}

Biochemical studies. The effect of cytochalasin B was tested on various metabolic pathways that are insulin sensitive. Cytochalasin B had no effect on basal or epinephrine- $(0.125 \mu \mathrm{g} / \mathrm{ml})$ stimulated lipolysis of the adipocyte (data not shown) as reported previously by Loten and Jeanrenaud (11). Insulin $(50 \mu \mathrm{U} / \mathrm{ml})$ inhibited epinephrine-stimulated lipolysis to the same extent in the presence or absence of cytochalasin B. The insulin concentration was chosen to give a submaximal inhibition of the lipolysis so that any minor

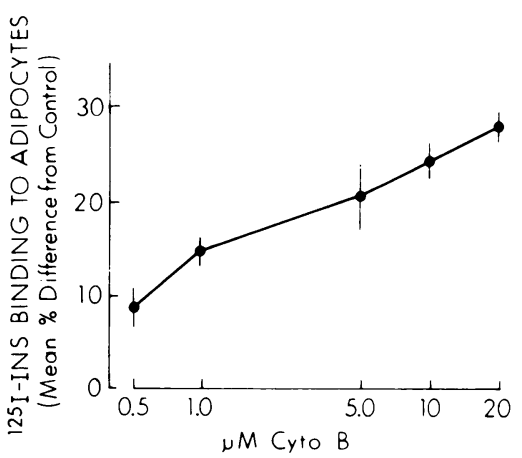

FigurE 1 The effect of cytochalasin B on ${ }^{125}$ I-labeled insulin ( ${ }^{125}$ I-INS) binding to adipocytes was determined by incubating adipocytes $\left(10^{5}\right.$ cells $\left./ \mathrm{ml}\right)$ for $15 \mathrm{~min}$ with $0-20 \mu \mathrm{M}$ cytochalasin $\mathrm{B}$ (Cyto B) before the addition of $50 \mu \mathrm{U} / \mathrm{ml}^{125} \mathrm{I}$-insulin. After $15 \mathrm{~min}$, the cells were diluted and filtered as described in Methods. Specific binding was determined in triplicate samples, and the effect of cytochalasin B on ${ }^{125}$ I-insulin binding was plotted to show the mean percent difference $( \pm$ SEM) from the control at each concentration of cytochalasin B. Nonspecific binding was determined in the presence of $5 \mu \mathrm{g}$ insulin $/ \mathrm{ml}$. Cytochalasin B had no effect on nonspecific binding, which accounted for $<20 \%$ of total binding.

effect of cytochalasin B would be found and not prevented by a supermaximal insulin concentration.

Cytochalasin B at $5 \mu \mathrm{M}$ had negligible effect on protein synthesis of the adipocyte (Table I). Insulin at 50 and $100 \mu \mathrm{U} / \mathrm{ml}$ produced a 47 and $88 \%$ stimulation of adipocyte protein synthesis as measured by $\left[{ }^{14} \mathrm{C}\right] \mathrm{his}-$ tidine incorporation into protein. Cy tochalasin B had no effect on the ability of insulin to stimulate protein syrithesis.

The effect of cytochalasin $\mathrm{B}$ on insulin binding to adipocytes was determined because it had been reported that a 2 -h incubation of IM-9 lymphocytes with high concentrations ( $>2 \mu \mathrm{M}$ ) of cytochalasin B caused significant inhibition of subsequent insulin binding to the cells (17). Fig. 1 shows that exposure of adipocytes to a range of cytochalasin $B$ concentrations (0.5-20 $\mu \mathrm{M})$ for $15 \mathrm{~min}$, followed by ${ }^{125} \mathrm{I}$-insulin $(50 \mu \mathrm{U} / \mathrm{ml})$ resulted in a small but progressive increase in the amount of insulin bound with increasing cytochalasin

\section{TABLE I}

Effect of $5 \mu$ M Cytochalasin B on Basal and Insulin-Stimulated Incorporation of $\left[{ }^{14} \mathrm{C}\right]$ Histidine into Adipocyte Protein

\begin{tabular}{lcc}
\hline \multicolumn{1}{c}{ Sample } & -Cytochalasin B & +Cytochalasin B \\
\hline & & $\%$ \\
Basal & 100 & $103 \pm 4.0$ \\
$50 \mu \mathrm{U}$ insulin $/ \mathrm{ml}$ & $147 \pm 3.1$ & $160 \pm 0.2$ \\
$100 \mu \mathrm{U}$ insulin $/ \mathrm{ml}$ & $188 \pm 6.8$ & $194 \pm 9.8$ \\
\hline
\end{tabular}


B concentrations. A maximum increase of $28 \%$ was found at $20 \mu \mathrm{M}$ cytochalasin $\mathrm{B}$.

The effect of cytochalasin B was measured on basal and insulin-stimulated glucose uptake as measured by glucose oxidation. Data in Table II show that cytochalasin B inhibited basal glucose transport in a progressive fashion reaching maximal at $5 \mu \mathrm{M}$. Addition of cytochalasin B before the addition of $50 \mu \mathrm{U}$ insulin/ $\mathrm{ml}$ resulted in an identical pattern of inhibition of insulin-stimulated glucose oxidation. Examination of these data by comparing the insulin-stimulated level of glucose transport in the presence of cytochalasin $B$ with the level at each comparable cytochalasin B concentration revealed that insulin stimulated the glucose transport by the "same percent regardless of the presence or absence of cytochalasin $B$ (Table II). The slightly greater stimulation at the 5$\mu \mathrm{M}$ cytochalasin $\mathrm{B}$ concentration reflects the difficulty in accurately measuring the low level of basal glucose oxidation. These data suggested that cytochalasin B acted only on the basal glucose transport system and did not interfere with the ability of insulin. to stimulate the remaining uninhibited basal activity.

Fig. 2 demonstrates the ability of insulin to partially protect against the cytochalasin $B$ inhibition of glucose oxidation. If cells were preincubated with $50 \mathrm{nM}-5$ $\mu \mathrm{M}$ of cytochalasin $\mathrm{B}$, a progressive inhibition was found of the insulin- $(250 \mu \mathrm{U} / \mathrm{ml})$ stimulated glucose oxidation. Pretreatment of adipocytes with insulin followed by the addition of cytochalasin B partially protected the glucose oxidation system from inhibition. Over a log greater concentration of cytochalasin B was needed to demonstrate inhibition of the insulinstimulated glucose oxidation if insulin was added first compared with cytochalasin B. This insulin effect was found to be dose dependent, with lower concentrations of insulin less effective (data not shown). Separate studies were performed measuring the effect of $1 \mu \mathrm{M}$

TABLE II

Effect of Cytochalasin B on Basal and Insulin-Stimulated Glucose Oxidation

\begin{tabular}{|c|c|c|c|}
\hline $\begin{array}{c}\text { Cyto- } \\
\text { chalasin B }\end{array}$ & Basal & Insulin* & $\begin{array}{l}\text { Percentage of } \\
\text { stimulation }\end{array}$ \\
\hline & \multicolumn{2}{|c|}{$\begin{array}{c}\text { nmol }{ }^{14} \mathrm{CO}_{2} \text { produced/mg } \\
\text { protein/h }\end{array}$} & $\%$ \\
\hline 0 & $8.9 \pm 0.3$ & $134.0 \pm 1.0$ & 1,502 \\
\hline $50 \mathrm{nM}$ & $8.6 \pm 0.7$ & $128.6 \pm 0.7$ & 1,500 \\
\hline $0.1 \mu \mathrm{M}$ & $8.2 \pm 0.2$ & $124.1 \pm 0.9$ & 1,511 \\
\hline $0.25 \mu \mathrm{M}$ & $6.4 \pm 0.3$ & $96.8 \pm 1.4$ & 1,503 \\
\hline $0.5 \mu \mathrm{M}$ & $4.5 \pm 0.3$ & $67.3 \pm 0.7$ & 1,506 \\
\hline $1 \mu \mathrm{M}$ & $2.5 \pm 0.3$ & $37.5 \pm 1.0$ & 1,501 \\
\hline $5 \mu \mathrm{M}$ & $0.3 \pm 0.2$ & $4.8 \pm 0.3$ & 1,865 \\
\hline
\end{tabular}

* Insulin concentration was $50 \mu \mathrm{U} / \mathrm{ml}$, and cytochalasin B was added to cells 15 min before insulin addition. All data represent means of triplicate determinations $\pm S E M$.

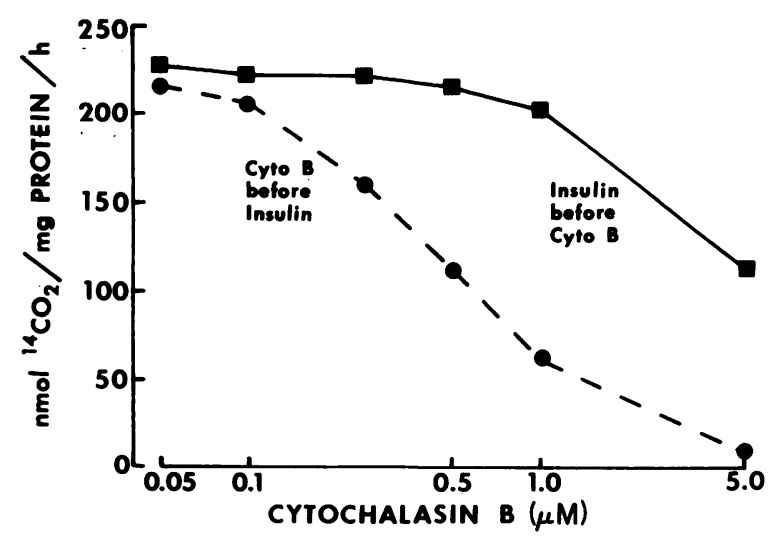

FIGURE 2 The protective effect of insulin on cytochalasin B (Cyto B) inhibition of adipocyte glucose oxidation was determined. One aliquot of isolated adipocytes was incubated with $250 \mu \mathrm{U}$ insulin $/ \mathrm{ml}$ for $15 \mathrm{~min}$ at $37^{\circ} \mathrm{C}$ before being added to vials containing various concentrations of cytochalasin $B$ as indicated ( $\square$ ). Another aliquot of cells was incubated with the cytochalasin $\mathrm{B}$ concentrations before being added to vials containing $250 \mu \mathrm{U}$ insulin $/ \mathrm{ml}(\Theta)$. The cells were then incubated for $60 \mathrm{~min}$ at $37^{\circ} \mathrm{C}$, and the conversion of $\mathrm{D}-\left[1-^{14} \mathrm{C}\right] \mathrm{glu}$ cose to ${ }^{14} \mathrm{CO}_{2}$ was determined as described in Methods. The values determined in the experiment, but not illustrated, were (in nanomoles ${ }^{14} \mathrm{CO}_{2}$ per milligram protein per hour): basal, $11.8 \pm 0.8 ; 250 \mu \mathrm{U}$ insulin/ml, 225:1 \pm 1.6 . Cytochalasin B inhibited basal glucose oxidation by $3.2-95.7 \%$. The values presented represent the mean of triplicate samples from a representative experiment. The SEMs were too small $(<1 \%)$ to be clearly illustrated.

of cytochalasin B on basal and insulin-stimulated glucose transport as determined by $\left[2-{ }^{14} \mathrm{C}\right]$ deoxyglucose and $\left[3-\mathrm{O}_{-}{ }^{3} \mathrm{H}\right]$ methylglucose transport. Similar to findings in the glucose oxidation studies, cytochalasin B inhibited the basal but not the insulin stimulation of the remaining basal transport, and preincubation with insulin partially protected against the cytochalasin B effects (data not shown). This suggests that the results from the glucose oxidation studies reflect the effects of cytochalasin B on glucose transport. Cytochalasin D, as would be expected, had no effect on either basal or insulin-stimulated glucose transport (data not shown).

Morphological studies. Studies were carried out with Fm-I and cytochalasin B under conditions similar to the biochemical studies for morphological quantitation of the groups of insulin receptors. An experiment illustrated in Fig. 3 showed that an increase in concentrations of cytochalasin B caused a progressive increase in the number of single receptors and a decrease in the number of larger groups of insulin receptors. The results of another set of experiments with additional cytochalasin B concentrations are illustrated in Fig. 4. The most dramatic change is seen in the increasing percentage of receptors found as single molecules. The singletons comprised $\cong 22 \%$ of the total receptors in the control and over $50 \%$ of the total 


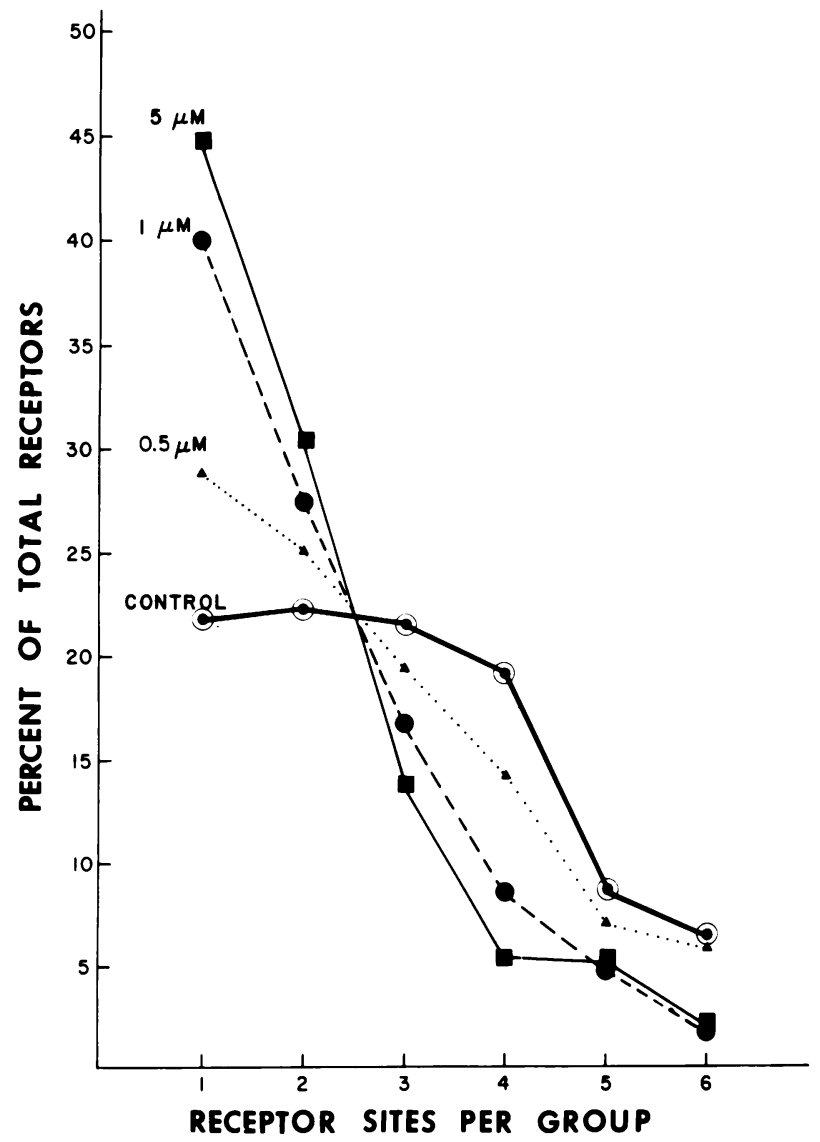

Figure 3 The effect of cytochalasin B on the distribution of $\mathrm{Fm}$-I receptors on adipocytes was determined by incubating adipocytes in the absence or presence of the indicated concentrations of cytochalasin $\mathrm{B}$ for $15 \mathrm{~min}$ at $37^{\circ} \mathrm{C}$ before the addition of $500 \mu \mathrm{U} / \mathrm{ml} \mathrm{Fm}$-I. After $30 \mathrm{~min}$ at $37^{\circ} \mathrm{C}$, the cells were washed and prepared for electron microscopic observation. The distribution of the $\mathrm{Fm}$-I receptors was analyzed as detailed in Methods. The results depicted represent a typical experiment, showing the percentage of the total receptors observed in each group size of from one to six receptor sites per group.

after treatment with $20 \mu \mathrm{M}$ cytochalasin $\mathrm{B}$. The decrease in the number of groups with three or four receptors was obvious. The number of receptors in groups of two appeared to be relatively consistent. This probably does not indicate that groups of two were not disrupted, because as the disruption of the larger group occurred, more groups with two receptor molecules would be formed. Thus, the most reliable index of disruption of the groups would be the percent increase in single receptors.

The similarity in the concentrations of cytochalasin $B$ required for inhibition of glucose transport (Table II) and for disruption of the groups of insulin receptors (Figs. 3 and 4) suggested a possible relationship between these two phenomena. A separate set of studies was performed in which morphological observations were carried out with one portion of an adipocyte preparation with $500 \mu \mathrm{U} \mathrm{Fm}-\mathrm{I} / \mathrm{ml}$, while the rest of the cells were used for the biochemical measurements of glucose oxidation with $500 \mu \mathrm{U}$ insulin/ml. These data are presented in Fig. 5. A significant correlation $(r$ $=0.964, P<0.001$ ) was found between the ability of cytochalasin B to inhibit glucose transport (as determined by glucose oxidation) and to disrupt the groups of insulin receptors (as determined by measurement of the percent increase in single receptors above control levels).

The ability of Fm-I to protect the groups of insulin receptors against disruption by cytochalasin B was tested, as insulin preincubation of cells was found to protect against the cytochalasin B inhibition of glucose oxidation (Fig. 2). Addition of Fm-I before the addition of cytochalasin B did partially protect the groups of insulin receptors from disruption (Fig. 6), similar to the biochemical studies.

Cytochalasin B is known to have at least two major effects on cells: inhibition of glucose transport (10) and alteration of cellular cytoskeletal elements, such

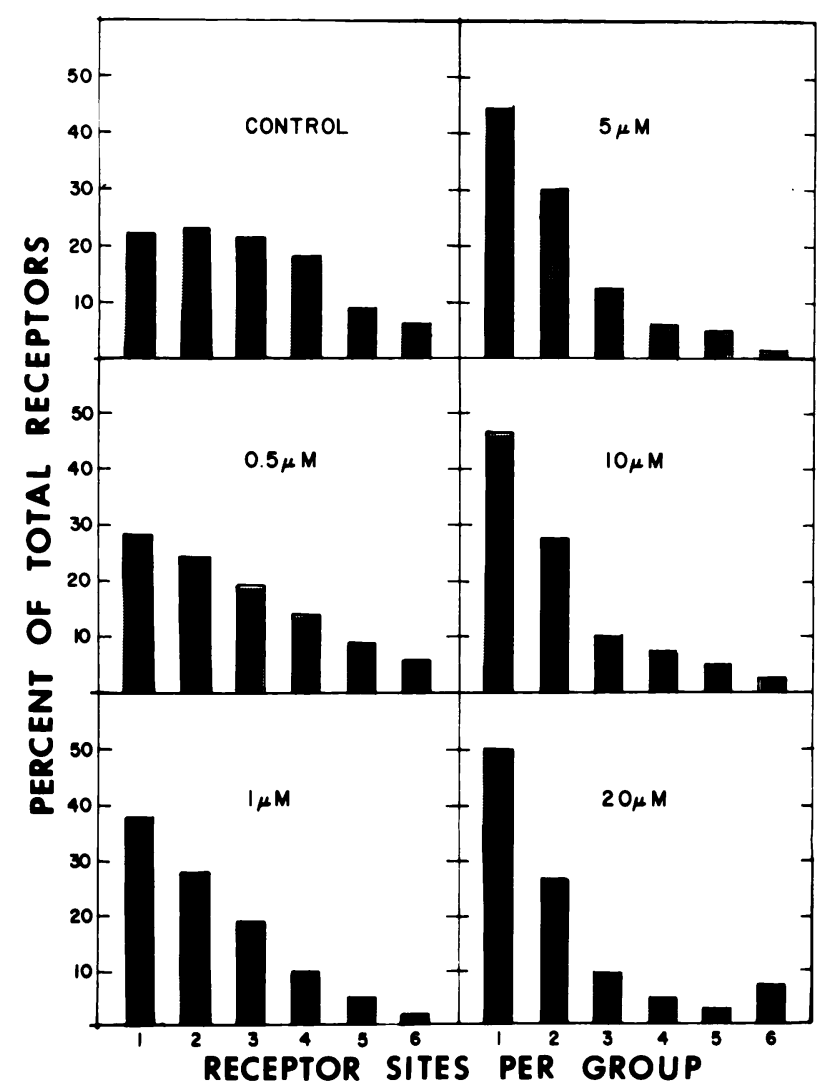

FIGURE 4 The effect of cytochalasin $\mathrm{B}$ on the distribution of $\mathrm{Fm}$-I receptors on adipocytes was determined in a series of up to five experiments as described in Methods and in the legend to Fig. 2. The results depicted represent the mean percentage of the total receptors observed in each group size of from one to six receptor sites per group. 


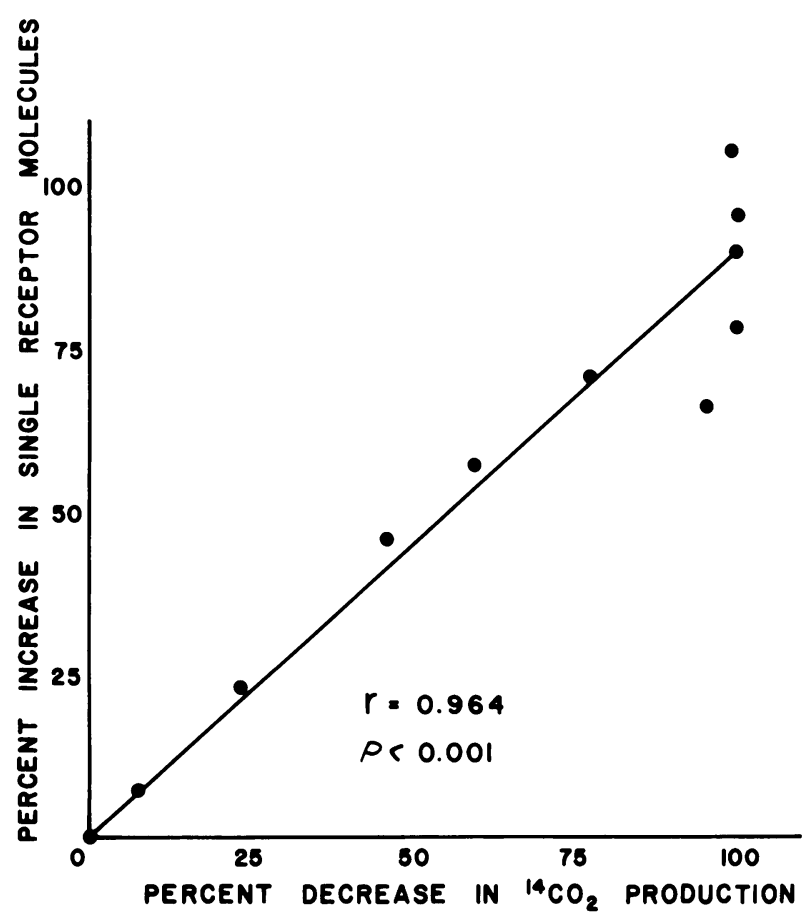

Figure 5 The effect of cytochalasin B on glucose oxidation and the distribution of $\mathrm{Fm}$-I receptors was determined when a single preparation of adipocytes was divided into two sets of cells. One set was used to determine the effectiveness of cytochalasin $\mathrm{B}$ in inhibiting glucose oxidation in the presence of $500 \mu \mathrm{U}$ insulin $/ \mathrm{ml}$; the other set was used to determine the distribution of insulin receptors after cytochalasin B treatment. Cytochalasin B concentrations were 0.1-20 $\mu \mathrm{M}$, and the details of incubation and analytical procedures are described in Methods. The data was plotted to illustrate the percent change between cells incubated with $500 \mu \mathrm{U}$ insulin or Fm-I per milliliter in the absence of cytochalasin $B$ and cells incubated with each concentration of cytochalasin B for both analyzed parameters.

as microfilaments and actin (18). Cytochalasin D does not inhibit glucose transport (19) but does alter microfilaments at even lower concentrations than cytochalasin B (20). Thus, the effects of cytochalasin D on the groups of insulin receptors was tested. Fig. 7 shows that cytochalasin D had no effect on the distribution of the groups of insulin receptors on the adipocyte surface, just as it had no effect on glucose oxidation by the adipocyte.

\section{DISCUSSION}

Previous ultrastructural studies have shown that insulin receptors are present in randomly distributed groups associated with the glycocalyx coating of the adipocyte plasma membrane (3-6). Data in one of these reports suggested that the groups are present before, and independent of, occupancy by the ligand (6), which indicated that the receptors are not randomly distrib- uted. Similar groups of insulin receptors have been found on microvilli of human placental syncytial trophoblasts (21). Naturally occurring groups of melanocyte-stimulating hormone receptors have also been reported (22). The questions to be addressed in this study concern whether the groups of insulin receptors were necessary for insulin action, and what physiological function these groups might have.

Cytochalasin B was capable of markedly altering the distribution pattern of insulin receptors in groups of various sizes. The most obvious effect of cytochalasin $B$ was to increase the number of single insulin receptor molecules and decrease the groups of three to four (Figs. 2 and 3). This disruption or alteration in receptor grouping occurred without affecting the action of insulin on membrane-related or intracellular processes. The biochemical data confirmed the findings of Loten and Jeanrenaud (11) that cytochalasin B had no effect on the antilipolytic effect of insulin. In addition, cytochalasin B had no effect on insulin stimula-

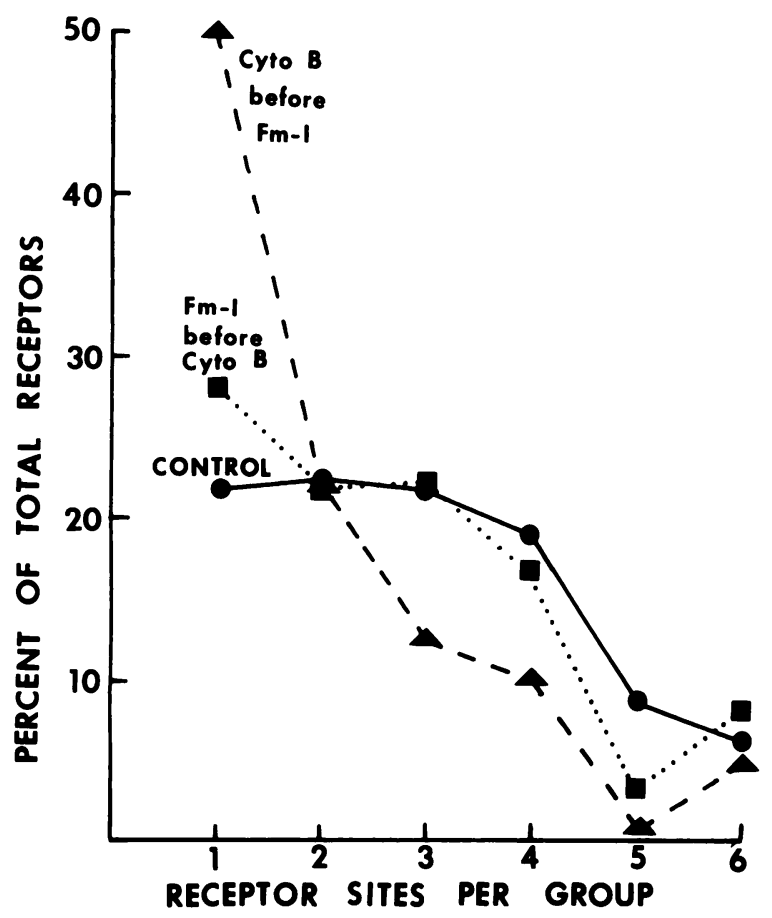

FIGURE 6 The protective effect of Fm-I on cytochalasin-Binduced redistribution of $\mathrm{Fm}-\mathrm{I}$ receptors was determined. One aliquot of adipocytes served as the control and was incubated with $500 \mu \mathrm{U} \mathrm{Fm}-\mathrm{I} / \mathrm{ml}$ for $30 \mathrm{~min}$ at $37^{\circ} \mathrm{C}(\bullet)$. A second aliquot was incubated with $500 \mu \mathrm{U} F \mathrm{~m}-\mathrm{I} / \mathrm{ml}$ for 15 min before the addition of $5 \mu \mathrm{M}$ cytochalasin B (Cyto B). These cells were incubated an additional $15 \mathrm{~min}$ at $37^{\circ} \mathrm{C}$ (ם). A third aliquot was incubated with $5 \mu \mathrm{M}$ cytochalasin B for $15 \mathrm{~min}$ before adding $500 \mu \mathrm{U} \mathrm{Fm}-\mathrm{I} / \mathrm{ml}$ and incubating for an additional $30 \mathrm{~min}$ at $37^{\circ} \mathrm{C}(\boldsymbol{\Delta})$. All cells were prepared for electron microscopy, and the receptor distribution was quantitated as described in Methods. The data presented are the results of a single experiment. 


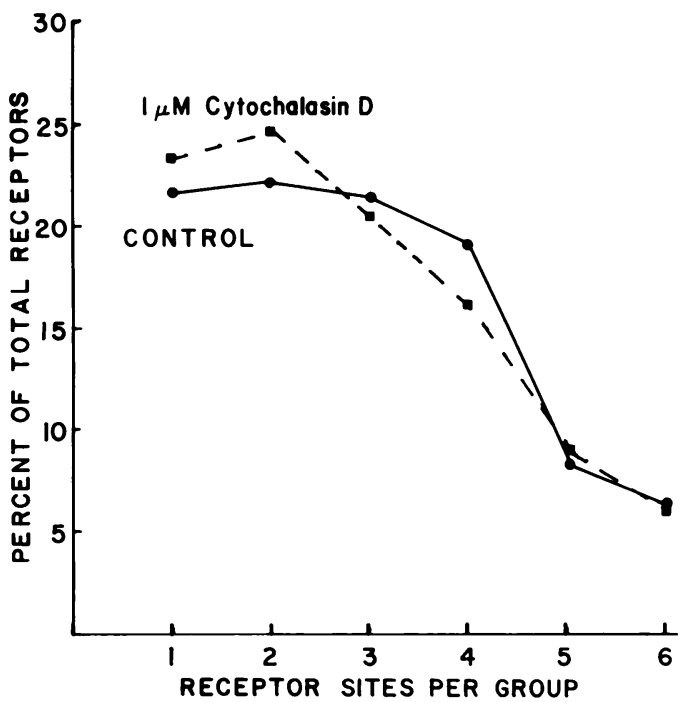

FIGURE 7 The effect of cytochalasin D on the distribution of $\mathrm{Fm}-\mathrm{I}$ receptors was determined by incubating adipocytes for $15 \mathrm{~min}$ at $37^{\circ} \mathrm{C}$ with $10 \mu \mathrm{M}$ cytochalasin $\mathrm{D}$ before the addition of $500 \mu \mathrm{U} / \mathrm{ml} \mathrm{Fm-I.} \mathrm{After} \mathrm{a} 30-\mathrm{min}$ incubation at $37^{\circ} \mathrm{C}$ the cells were prepared for electron microscopy and analysis as described in Methods. The results depicted show the percentage of the total insulin receptors observed found in each group size from one to six receptor sites per group in the control $(\Theta)$ or cytochalasin-D-treated $(\square)$ cells.

tion of protein synthesis. Cytochalasin B was capable of inhibiting the basal glucose transport system, and thereby prevented insulin from stimulating the disrupted basal system. However, any remaining uninhibited basal glucose transport was responsive to insulin to the same extent as in the absence of any cytochalasin B. This is consistent with the data of Czech et al. (10). Thus, it would appear that maximum disruption of the groups of insulin receptors by cytochalasin B did not interfere with insulin action. At least three explanations exist for this. First, and most likely, the glycoproteins to which insulin binds contain the mechanism for initiating insulin action and can function whether part of a group or not. The second is that not all of the groups are disrupted, and the remaining ones can account for maintaining insulin action through spare receptors $(23,24)$; however, concentrations of cytochalasin B that caused maximal disruption of receptor groups did not alter the actions of insulin at submaximal concentrations of insulin (making this explanation unlikely). A third possibility is that there are two functionally distinct types of groups of insulin receptors: one group is sensitive to cytochalasin B and relates to glucose transport as discussed below; and the second type of group is insensitive to, and not disrupted by, cytochalasin B and may account for all other actions of insulin.

The data in this study would suggest that the groups of glycoproteins containing the insulin receptors, or at least a subset of them, function as a structural part of the glucose transport system. A number of lines of evidence support this theory. First, several experimental conditions showed a correlation of morphological and biochemical observations with cytochalasins. Disruption of the groups of insulin receptors occurred over the same concentration range of cytochalasin $B$ that inhibited glucose transport. Cytochalasin D over the same concentration range had no effect on glucose transport or on the groups of insulin receptors. Pretreatment of adipocytes with insulin protected glucose transport from inhibition by cytochalasin B and other inhibitors of glucose transport such as $\mathrm{N}$-ethylmaleimide (25), and the pretreatment with insulin prevented disruption of the groups of insulin receptors by cytochalasin B. Secondly, antibodies to the partially purified adipocyte hexose transport system mimic insulin by stimulating glucose transport (26) and inhibiting stimulated lipolysis. ${ }^{2}$ Thirdly, there appears to be the same number of cytochalasin B binding sites associated with the glucose transport system of adipocyte plasma membranes (27) as has been previously reported for insulin binding sites based on biochemical and morphological data (3).

Singer (28) and Guidotti (29) have recently proposed a structural model for transport based on integral proteins aggregating into groups of various sizes (two to four) and forming an aqueous channel. A number of transport proteins have been identified which fit this model, such as the $\mathrm{Na}^{+}-\mathrm{K}^{+}$-ATPase (30), the erythrocyte band 3 anion transport protein (31), the bacteriorhodopsin in the purple membranes which transport $\mathrm{H}^{+}$ions (32), rhodopsin (33), the $\mathrm{Ca}^{++}$ATPase of sarcoplasmic reticulum (34), and the acetylcholine receptor (35). The data present in this report are consistent with such a model, which suggests that the groups of insulin receptors form the glucose transport pore. This would explain why disruption of the groups by cytochalasin B inhibits the basal glucose transport system, and would suggest that the grouping of insulin receptor glycoproteins are necessary for basal transport to occur.

Another physiological function of the groups, besides forming the glucose transport pore, might be to facilitate microredistribution of receptors after occupancy by insulin. The data of Kahn et al. (36), from studies with antibodies to insulin receptor that mimic insulin action, suggest that microredistribution of the receptors might be important in initiating insulin action. Bivalency of the antibody or its fragments was essential for the insulin-like effects. Ultrastructural studies have shown a slight difference between pre-

${ }^{2}$ Pillion, D. J., J. R. Grantham, and M. P. Czech. 1979.J. Biol. Chem. In press. 
fixed and $0-4^{\circ} \mathrm{C}$-incubated membranes in the distribution of the insulin receptors in groups of various sizes (6). This may be consistent with microredistribution of the receptors occurring. In contrast, a number of arguments can be made against the microredistribution being necessary for insulin action. First, a single insulin molecule is normally considered to be monomeric, not bivalent as is the receptor antibody. Second, the marked disruption of the groups of insulin receptors by cytochalasin B did not alter the biological effects of insulin, even though it would be more difficult for microredistribution to occur after disruption of the groups. Finally, it is not clear yet as to the mechanism by which the antibody actually mimics insulin. Antibodies to both the insulin receptor $(36,37)$ and the glucose transport system (26) mimic insulin as does concanavalin A (38). All of these multivalent ligands may cause major alterations in the membrane that differs from the actual mechanism of insulin action, but result in activation of a common subsequent pathway. This is especially true in light of recent data (39), which shows that anti-insulin receptor antibodies have a similar magnitude of effect as insulin on 2-deoxyglucose uptake and glycolysis, but a smaller effect on glycogen synthesis than insulin, all in skeletal muscle. Caution must be exercised at this time in the interpretation of the antibody data as to its implications to the mechanism of insulin action.

The actin or actin-myosin cytoskeletal system would not appear to be involved in the mechanism of insulin action or in holding the groups of insulin receptors together. Both cytochalasin B and D disrupt microfilaments $(18,40)$ and interfere with actin gelation $(9,41)$, with cytochalasin D even more effective than cytochalasin B. The concentrations of cytochalasin B used in this study were at the lower level of effective concentrations that disrupt microfilaments or interfere with actin gelatin in other cell systems studied. In contrast, the cytochalasin D levels were at the high end of the effective range. Cytochalasin $B$ has a unique binding site not shared with cytochalasin $\mathrm{D}$, which has been related to the glucose transport glycoprotein system (19). Cytochalasin B, but not cytochalasin D, inhibited glucose transport and disrupted insulin receptor groups. Thus, the disruption of the groups of insulin receptors concomitant with the inhibition of glucose transport suggests that the disruption relates to the mechanism by which cytochalasin B inhibits glucose transport rather than any action on microfilaments or actin gelation. The mechanism by which cytochalasin B inhibits glucose transport is not known, but has been suggested (42) to be because of competitive binding with glucose on the glucose transport glycoprotein as a result of an identical spatial distribution of four oxygen atoms to those found in the Cl conformation of $\beta$-D-glucopyranose. These bio- chemical and morphological observations should provide a test system for further study into the mechanism by which insulin and cytochalasin B act on the glucose transport system.

\section{ACKNOWLEDGMENTS}

This study was supported, in part, by U. S. Public Health Service grants AM-11892 and AM-20097, and a grant from the Juvenile Diabetes Foundation.

\section{REFERENCES}

1. Cuatrecasas, P. 1974. Membrane receptors. Annu. Rev. Biochem. 43: 169-214.

2. Catt, K. J., and M. L. Dufau. 1977. Peptide hormone receptors. Annu. Rev. Physiol. 39: 529-557.

3. Jarett, L., and R. M. Smith. 1976. Ultrastructural approaches to the study of hormone receptors: the use of ferritin-insulin in the localization of biologically relevant insulin receptors. In Cell Membrane Receptors for Viruses, Antigens and Antibodies, Polypeptide Hormones and Small Molecules. R. F. Beers, Jr. and E. G. Basset, editors. Raven Press, New York. 91-104.

4. Jarett, L., and R. M. Smith. 1974. Electron microscopic demonstration of insulin receptors on adipocyte plasma membranes utilizing a ferritin-insulin conjugate. J. Biol. Chem. 249, 7024-7031.

5. Jarett, L., and R. M. Smith. 1975. Ultrastructural localization of insulin receptors on adipocytes. Proc. Natl. Acad. Sci. U. S. A. 68: 3526-3530.

6. Jarett, L., and R. M. Smith. 1977. The natural occurrence of insulin receptors in groups on adipocyte plasma membranes as demonstrated with monomeric ferritininsulin. J. Supramol. Struct. 6: 45-59.

7. Nicolson, G. 1976. Transmembrane control of the receptors on normal and tumor cells. I. Cytoplasmic influence over cell surface components. Biochim. Biophys. Acta. 457: 57-108.

8. Scott, R. E., P. B. Maercklein, and L. T. Furcht. 1977. Plasma membrane intramembranous particle topography in 3T3 and SV3T3 cells: the effect of cytochalasin B. J. Cell Sci. 23: 173-192.

9. Weihing, R. R. 1976. Cytochalasin B inhibits actin-related gelation of HeLa cell extracts. J. Cell. Biol. 71: 303-307.

10. Czech, M. P., D. G. Lynn, and W. S. Lynn. 1973. Cytochalasin B-sensitive 2-deoxy-D-glucose transport in adipose cell ghosts. J. Biol. Chem. 248: 3636-3641.

11. Loten, E. G., and B. Jeanrenaud. 1974. Effects of Cytochalasin $\mathrm{B}$, colchicine and vincristine on the metabolism of isolated fat cells. Biochem. J. 140: 185-192.

12. Rodbell, M. 1964. Metabolism of isolated fat cells. I. Effects of hormones on glucose metabolism and lipolysis. J. Biol. Chem. 239: 375-380.

13. Jarett, L., A. L. Steiner, R. M. Smith, and D. M. Kipnis. 1972. The involvement of cyclic AMP in the hormonal regulation of protein synthesis in rat adipocytes. Endocrinology. 90: 1277-1284.

14. Lowry, O. H., J. V. Passoneau, F. X. Hasselberger, and D. W. Schultz. 1964. Effect of ischemia on known substrates and cofactors of the glycolytic pathway in brain. J. Biol. Chem. 239: 18-30.

15. Mans, R. J., and G. D. Novelli. 1960. A convenient, rapid and sensitive method for measuring the incorporation of radioactive amino acids into proteins. Biochem. Biophys. Res. Commun. 3: 540-543. 
16. Gliemann, J. 1967. Assay of insulin-like activity by the isolated fat cell method. I. Factors influencing the response to crystalline insulin. Diabetologia. 3: 382-388.

17. Van Obberghen, E., P. DeMeyts, and J. Roth. 1976. Cell surface receptors for insulin and growth hormone; effects of microtubule and microfilament modifiers. J. Biol. Chem. 251: 6844-6851.

18. Wessels, N. K., B. S. Spooner, J. F. Ash, M. O. Bradley, M. A. Luduena, E. L. Taylor, J. T. Wrenn, and K. M. Yamada. 1971. Microfilaments in cellular and developmental processes. Contractile microfilament machinery of many cell types is reversibly inhibited by cytochalasin B. Science (Wash. D. C.). 171: 135-143.

19. Tannenbaum, J., S. W. Tanenbaum, and G. G. Godman. 1977. The binding sites of cytochalasin D. II. Their relationship to hexose transport and to cytochalasin B.J. Cell. Physiol. 91: 239-248.

20. Atlas, S. J., and S. Lin. 1978. Dihydrocytochalasin B. Biological effects and binding to 3T3 cells. J. Cell Biol. 76: $360-370$.

21. Nelson, D. M., R. M. Smith, and L. Jarett. 1978. Nonuniform distribution and grouping of insulin receptors on human placental syncytial trophoblast. Diabetes. 27: 530538.

22. Varga, J. M., M. H. Saper, A. B. Lerner, and P. Fritsch, 1976. Non-random distribution of receptors for melanocyte-stimulating hormone on the surface of mouse melanoma cells. J. Supramol. Struct. 4: 45-49.

23. Kono, T., and F. W. Barham. 1971. The relationship between the insulin binding capacity of fat cells and the cellular response to insulin. J. Biol. Chem. 246: 6210_ 6216.

24. Gliemann, J., S. Gammeltoft, and J. Vinten. 1975. Time course of insulin receptor binding and insulin induced lipogenesis in isolated rat fat cells. J. Biol. Chem. 250: $3368-3374$

25. Czech, M. P. 1976. Regulation of the D-glucose transport system in isolated fat cells. Mol. Cell. Biochem. 11: 51-63.

26. Pillion, D. J., and M. P. Czech. 1978. Antibodies against intrinsic adipocyte plasma membrane proteins activate D-glucose transport independent of interaction with insulin binding sites. J. Biol. Chem. 253: 3761-3764.

27. Wardzala, L. J., S. W. Cushman, and L. B. Salans. 1978. Demonstration of a D-glucose sensitive cytochalasin B binding site in rat adipose cell plasma membranes: tentative identification as the glucose transport system. Diabetes. 27(suppl. 2): 453 .
28. Singer, S. J. 1977. Thermodynamics, the structure of integral membrane proteins, and transport. J. Supramol. Struct. 6: 313-323.

29. Guidotti, G. 1977. The structure of intrinsic membrane proteins. J. Supramol. Struct. 7: 489-497.

30. Dahl, J. L., and L. E. Hokin. 1974. The sodium-potassium adenosenetriphosphatase. Annu. Rev. Biochem. 43: $327-356$.

31. Ho, M. K., and G. Guidotti. 1975. A membrane protein from human erythrocytes involved in anion exchange. J. Biol. Chem. 250: 675-683.

32. Henderson, R., and P. N. T. Unwin. 1975. Three dimensional model of purple membrane obtained by electron microscopy. Nature (Lond.). 257: 28-32.

33. Cone, R. A. 1972. Rotational diffusion of rhodopsin in the visual receptor membrane. Nat. New Biol. 236: 39-43.

34. McLennan, D. H., and P. C. Holland. 1975. Calcium transport in sarcoplasmic reticulum. Annu. Rev. Biophys. Bioeng. 4: 377-404.

35. Karlin, A. 1974. The acetylcholine receptor: progress report. Life Sci. 14: 1385-1415.

36. Kahn, C. R., K. L. Baird, D. B. Jarrett, and J. S. Flier. 1978. Monovalent anti-receptor antibodies regain insulinomimetic actions when cross-linked by a second antibody. Diabetes. 27(suppl. 2): 449. (Abstr.)

37. Jacobs, S., K-J. Chang, and P. Cuatrecasas. 1978. Antibodies to purified insulin receptor have insulin-like activity. Science (Wash. D. C.). 200: 1283-1284.

38. Cuatrecases, P. 1973. Interaction of concanavalin A and wheat germ agglutinin with the insulin receptor of fat cells and liver. J. Biol. Chem. 248: 3528-3534.

39. LeMarchand-Brustal, Y., P. Gorden, J. S. Flier, C. R. Kahn, and P. Freychet. 1978. Anti-insulin receptor antibodies inhibit insulin binding and stimulate glucose metabolism in skeletal muscle. Diabetologia. 14: 311-317.

40. Mousa, G. Y., and J. R. Trevithick. 1977. Differentiation of rat lens epithelial cells in tissue culture. II. Effects of cytochalasins B and D on actin organization and differentiation. Dev. Biol. 60: 14-25.

41. Mimura, N., and A. Asano. 1978. Actin-related gelation of Ehrlich tumour cell extracts is reversibly inhibited by low concentrations of $\mathrm{Ca}^{2+}$. Nature (Lond.). 272: 273276.

42. Taylor, N. F., and G. L. Gagneja. 1975. A model for the mode of action of cytochalasin $B$ inhibition of Dglucose transport in the human erythrocyte. Can. J. Biochem. 53: 1078-1084. 